\title{
Vegetation diversity and its interspecies association with merbau (Intsia bijuga) at three habitats of tropical rain forest in West Papua, Indonesia
}

\author{
SUSANTI TASIK ${ }^{1,2, \vartheta}$, SITI MUSLIMAH WIDYASTUTI ${ }^{3, v \vee}$, MUSYAFA $^{3, v \vee v}$, PRIYONO SURYANTO $^{3, v v v v}$ \\ ${ }^{1}$ Forestry Graduate Program, Universitas Gadjah Mada. Jl. Agro No. 1, Bulaksumur, Sleman 55281, Yogyakarta, Indonesia. \\ ${ }^{2}$ Faculty of Forestry, Universitas Papua. Jl. Gunung Salju, Amban, Manokwari 98314, West Papua, Indonesia. "email: susantitasik77@ gmail.com \\ ${ }^{3}$ Departement of Forest Silviculture, Forestry Faculty, Universitas Gadjah Mada. Jl. Agro No. 1, Bulaksumur, Sleman 55281, Yogyakarta, Indonesia. \\ Tel.: +62-274-512102, 6491420, Fax.: +62-274-55541, “vemail: smwidyastuti@ugm.ac.id, vwv musyafa@ ugm.ac.id, "vvv psuryanto@ugm.ac.id
}

Manuscript received: 20 May 2021. Revision accepted: 23 July 2021

\begin{abstract}
Tasik S, Widyastuti SM, Musyafa, Suryanto P. 2021. Vegetation diversity and its interspecies association with merbau (Intsia bijuga) at three habitats of tropical rain forest in West Papua, Indonesia. Biodiversitas 22: 3383-3391. The stability of vegetation community indicated by species diversity, structure and composition affects the relationship between species. The understanding of interspecies association in their natural habitat is important especially for management and conservation strategies of species with particular interest, including merbau (Intsia bijuga O. Colebr Kuntze), a timber tree species with high commercial value. This study aims to investigate the diversity and composition of vegetation coexisting with merbau, and to see whether there is pattern of interspecies association with merbau. Vegetation analyses of species richness, diversity index, evenness index and interspecies relationship were conducted at three research locations in West Papua, Indonesia, namely Mount Meja Natural Tourism Park (Hutan Taman Wisata Alam Gunung Meja/HTWAGM), Bembab Beach Forest of South Manokwari (Hutan Bembab Pantai Manokwari Selatan/HBPMS) and Bembab Mountain Forest of South Manokwari (Hutan Bembab Gunung Manokwari Selatan/HBGMS). The results showed that the species Caryota rumphiana, Licuala sp 1, Calophyllum inophyllum, Garcinia pichoriza, Pometia coreacea and Pometia pinnata always grew side by side with Intsia bijuga in three locations. Furthermore, the association analysis indicated a positive and strong relationship between Intsia bijuga and Pometia coreacea, Licuala sp1, Licuala sp 2, Caryota rumphiana at all three research sites. In addition, Pometia coracea had the highest Chi-square value $\left(\mathrm{X}^{2}=20.00\right)$ with the value of the three association indexes reached maximum value. We also found that the vegetation communities in the habitat of merbau had varying vegetation structure and composition as well as biodiversity indicators, yet they were all at stable state. The finding on vegetation analyses was confirmed with the result of soil analyses in which the physical and chemical properties had optimal conditions for vegetation to grow, including for merbau.
\end{abstract}

Keywords: Association patterns, companion vegetation, diversity, site quality

\section{INTRODUCTION}

Merbau (Intsia bijuga O. Colebr Kuntze) is a timber tree species with high commercial value. Merbau can live in a broad range of habitats, from coastal areas with high salinity level up to higher areas with an altitude of 1000 meters above sea level (Hou 1994; Nugroho and Mansur 2020). Such high adaptability enables merbau to live in a broad range of vegetation communities in which in some cases could triggers association between merbau and other species in the community.

Arsyad (2017) states that in an ecosystem there are several possible relationships between organisms, including positive associations, negative associations, or no association. A positive association occurs when the presence of a species is simultaneous with the presence of other species, or there is a pair of species that are often encountered more than expected. Association is negative if the presence of a species is not simultaneous with the absence of other species or the co-occurrence of pairs of species is less than expected.

In natural habitats, vegetation diversity strongly determines the optimal condition for the vegetation community to grow along with soils condition and microclimate factors (Schulte et al. 2014). At species level, the combination of such biotic and abiotic factors affects the growth and spread/dispersion of a species, including merbau. The knowledge about abiotic variables along with vegetation structure and composition in the habitat merbau is important for the management and conservation strategies of merbau, especially to determine the optimal environmental conditions for the growth of the species along with its vegetation community in natural forests.

This study aims to investigate the diversity and composition of vegetation coexisting with merbau and to see whether there are patterns of association. In doing so, analysis of species richness, diversity index, evenness index and interspecies relationship is conducted in this research. Three research locations in West Papua, Indonesia, namely Mount Meja Natural Tourism Park (Hutan Taman Wisata Alam Gunung Meja/HTWAGM), Bembab Beach Forest of South Manokwari (Hutan Bembab Pantai Manokwari Selatan/HBPMS) and Bembab Mountain Forest of South Manokwari (Hutan Bembab Gunung Manokwari Selatan/HBGMS), provide excellent context for data collection since such locations are the original habitats of merbau that represent coastal to mountainous habitats. 


\section{MATERIALS AND METHODS}

\section{Study area}

The research was conducted in lowland rainforests in Mount Meja Natural Tourism Park (Hutan Taman Wisata Alam Gunung Meja/HTWAGM), located at ( $0^{0}$ 51' 34.31" $\left.\mathrm{N} ; 134^{0} 44^{\prime} 8.48^{\prime \prime} \mathrm{E}\right)$ with an altitude of 70-170 meters above sea level (m asl.) (Sadono et al. 2014), Bembab Beach Forest of South Manokwari (Hutan Bembab Pantai Manokwari Selatan/HBPMS) located at $\left(1^{0} \quad 24^{\prime} 17.42^{\prime \prime} \mathrm{N} ; 134^{0} \quad 12^{\prime}\right.$ 51.30 " E) with elevation of 0-27 m asl, and Bembab Mountain Forest of South Manokwari (Hutan Bembab Gunung Manokwari Selatan/HBGMS) located at $\left(1^{0} 24^{\prime} 33.75^{\prime \prime} \mathrm{N}\right.$; $\left.134^{0} 12^{\prime} 41.96^{\prime \prime} \mathrm{E}\right)$ with an altitude of 175-186 $\mathrm{m}$ asl.

\section{Sampling and data collection}

The research data collection was carried out on 15 observation plots across all three research locations. Each observation plot area had an extent of 1 ha, resulting in the total observation plot at the three research locations was 15 ha. The determination of the position and size of the plot used a compass and roll meter. The observation plot design referred to the plot monitoring design used in Forest Health Monitoring/FHM (Mangold 1997; Safe'i et al. 2019) which was placed across all three research sites. The placement of observation plots was purposively based on the occurrence of merbau (Intsia bijuga) stands that grow naturally.

In each observation plot, four nested annual sub-plots were established for observation and data collection, namely-annular plots with radius a of 17.95 meters for data collection at tree level, annular plot with a radius of 7.32 meters for pole level, annular plot with a radius of 2.07 meters for sapling and seedling level. Species identification was carried out directly in the field using morphological characters found such as leaves, bark, sap, branching and assisted by professionals in the identification of plant species.

Growth components, such as brach-free and diameter, were recorded and tabulated. For identification, we collected the herbarium specimens and bought to the Herbarium Papuense of Forestry and Environment Research and Development Unit (Balai Penelitian dan Pengembangan Lingkungan Hidup dan Kehutanan) Manokwari and Herbarium Manokwariense (MAN), Research Center for Biodiversity (Pusat Penelitian Keanekaragam Hayati) Universitas Papua (PPKHUNIPA), Manokwari. The species name was updated according to The Plant List (TPL) at the website of http://www.theplantlist.org/.

\section{Data analysis}

Several analyses on biodiversity indicators were conducted including Margalef species richness index (Magurran 1988; Odum 1996; Maulana et al. 2019), Sorensen similarity index based on Sorenson formula (1948) as in Odum (1996), Shannon-Wiener diversity index (H') (Krebs 1994; Pamoengkas et al. 2018; Maulana et al. 2019), and Pielou evenness index (Odum 1996; Maulana et al. 2019). Analysis on interspecies relationship between merbau and other species was determined using contingency tables (Greig-Smith 1983; Maulana et al. 2019) with Chi-square formula at confident interval of $5 \%$ (Ludwig and Reynolds 1988; Sirami et al. 2019). Soil analysis was conducted at the Agricultural Technology Assessment Center (BPTP) Yogyakarta to analyze soil chemistry $\left(\mathrm{pH}\left(\mathrm{H}_{2} \mathrm{O}\right)\right.$, C-organic and CEC), essential macronutrients ( $\mathrm{P}$ and $\mathrm{K}$ available, $\mathrm{Ca}$ and $\mathrm{Mg}$,) and essential micronutrients (Fe, $\mathrm{Mn}$, and $\mathrm{Zn}$ ) with total 45 samples.
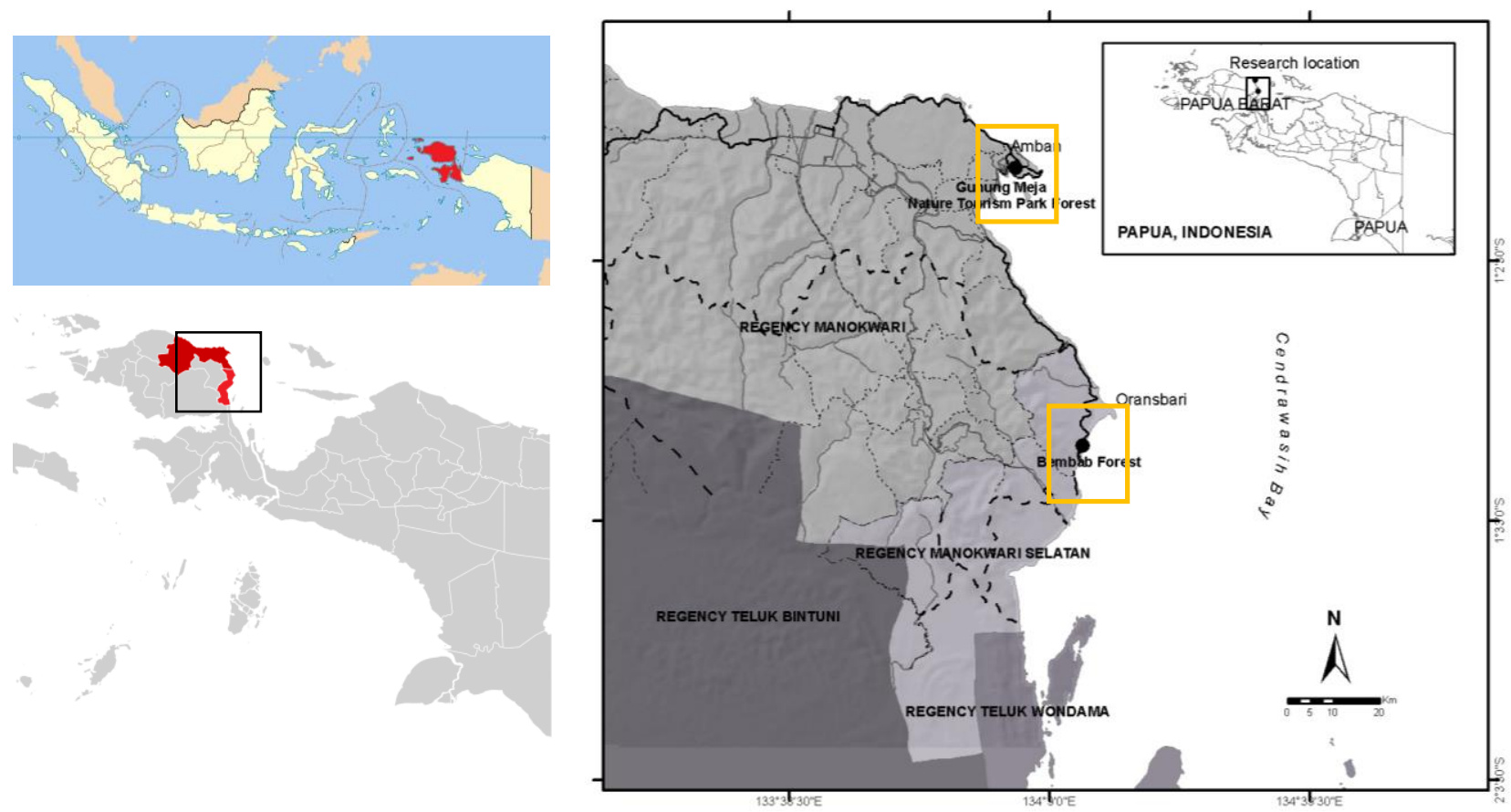

Figure 1. The map of study location in Mount Meja Natural Tourism Park and Bembab Forest in West Papua Province, Indonesia 


\section{RESULTS AND DISCUSSION}

\section{Diversity of vegetation coexisting with merbau}

In total, there were 72 species from 31 families that coexisted with merbau across the three research locations (Table 1). There were 16 species $(22.22 \%)$ from 14 families found in all location, 18 species $(25 \%)$ from 14 families in two location and 38 species (52.78\%) from 23 different families in only one research site.

Species that were found in all three research locations were dominated by the families of Arecaceae namely Caryota rumphiana and Licuala sp 1., Clusiaceae namely Calophyllum inophyllum and Garcinia pichoriza and Sapindaceae namely Pometia coreacea and Pometia pinnata. This result suggests that such species have the ability to adapt with varying soils and climate conditions (Table 4).

Species that were found in two research locations were dominated by the families of Euphorbiaceae namely Endospermum moluccanum, Macaranga aleuritoides, and Spathiostemon javensis; Apocynaceae with Alstonia scholaris and Alstonia macrophylla; and Leguminosae with Inocarpus fagifer and Maniltoa browneoides. Of the seven species found in two locations, as many as four species were found in HTWAGM and Bembab coastal forests namely A. scholaris, M. aleuritoides, E. moluccanum and $I$. fagifer. The species is likely to have a preference for typical soil conditions in which based on soil analysis (Table 4) both locations had $\mathrm{N}-\mathrm{NH}_{4}$ content values on medium-very high criteria. In contrast, such species were not found in mountain Bembab forests due to the low $\mathrm{NH}_{4}$ content value. On the other hand, three species were found in TWAGMM and Bembab mountain forests namely $A$. macrophylla, S. javensis, and M. browneoides. The two locations had different soil conditions with Bembab coastal forest which the availability of $\mathrm{P}_{2} \mathrm{O}_{5}, \mathrm{Ca}$ and $\mathrm{Mn}$ were more abundant (very high) (Tabel 4).

Species that were found only in one location were dominated by the Anacardiaceae family namely Buchanania arborescens, Dracontomelum dao, Mangivera minor and Rhus taitensis; Moraceae namely Artocarpus altilis, Ficus benjamina, Ficus septica and Ficus variegata; and Euphorbiaceae namely Macaranga mappa, Mallotus philippensis and Mallotus rhizinoides. The existence of such species that grew only at one location, is likely because the species requires special conditions to grow despite some of them were belong to similar families. For example, from the family Anacardiaceae, species $B$. arborescens, M. minor and R. taitensis grew on Bembab coastal forest, while $D$. dao grew on Bembab mountain forest. From Moraceae family, $F$. benjamina and $F$. variegata grew on HTWAGM, A. altilis grew on Bembab coastal forest and $F$. septica grew on Bembab mountain forest.

Among the species found in this study, there were seven species of 23 species mentioned by Thaman (2006) that have association with merbau. These were Dyospyros hebecarpa, Pandanus sp. which were found at all three research sites; Cananga odorata which was found in two research sites, namely in Mount Meja Natural Tourism Park and Bembab mountain forest; and Ficus sp., Hibiscus tiliaceus, Inocarpus fagifer, and Maniltoa brownneoide which were only found in one location. Sirami et al. (2019) also reported that these species Aglaia odorata, Antiaris toxicaria, Calophyllum inophyllum, Canarium hirsutum, Dyospyros hebecarpa, Garcinia pichorhiza, Palaquium amboinense, Pimeliodendron amboinicum, Pometia coreaceae, Pometia pinnata, Premna corymbosa, Pterygota horsfieldii, and Syzygium malaccense which were founded at Meja Mount Natural Tourism Park.

The presence of species that were found coexisting with merbau, indicates a close relationship (association) between both of them. The association components analyzed include the index, type, and association relationship of vegetation species that coexist with merbau at all three research locations as presented in Table 2.

There were two types of association between merbau and other species that grew naturally side by side in the three forest areas. Pometia coreacea, Caryota rumphiana, Licuala sp.1 and Licuala sp.2 had positive and strong association with merbau (Table 2) with P. coreacea had the highest Chi-square value $\left(\mathrm{X}^{2}=20.00\right)$ all three association indexes with value of $\mathrm{IO}=0.94-1.00$; ID $=0.93-1.00$; and $\mathrm{IJ}=0.88-1.00$. The positive association indicates a mutually beneficial relationship between two species (Kershaw 1964; Su et al. 2015). According to Sirami et al. (2019) P.coreacea, Spathioestemon javensis, Palaquium amboinense and Pimeliodendron amboinicum has the highest association in Gunung Meja Nature Tourism Park of Manokwari. Based on observations at the research locations, P. coreacea was always found at the nested plots growing side by side with merbau, within the distance of 310 meters. The presence of associated species indicates that both species have similar preference on environmental characteristics, for example, site that tends to be humid sunlight less shady (Windusari et al. 2011).

This study found a unique phenomenon, where there were two types of association between merbau and $C$. hirsutum. The first was a negative association $(\mathrm{R} 2=4.80)$ with weak relationships $(\mathrm{IO}=0.24 ; \mathrm{ID}=0.19 ; \mathrm{IJ}=0.11)$ which was found in HBPMS (Bembab coastal forest). The other is positive associations $\left(\mathrm{R}^{2}=6.11\right)$ with strong relationships $(\mathrm{IO}=0.83 ; \mathrm{ID}=0.81 ; \mathrm{IJ}=0.69)$ which found in HBGMS (Bembab mountain forest). This finding suggests that the relationship is not always exclusive to one form, either positive or negative, which is in line with Canastares et al. (2017) that reported similar results. Pratama et al. (2012) explained that negative associations show no tolerance for co-living in the same area or the absence of mutually beneficial relationships. Furthermore, the increasing variety of species in a plant community presents an opportunity for competition between individuals in types that finally forms a diverse composition and dominance (Solikin 2015). 
Table 1. List species coexisting with merbau at the research sites in Mount Meja Natural Tourism Park (HTWAGM), Bembab coastal forest (HBPMS) and Bembab mountain forest (HBGMS) in West Papua Province, Indonesia

\begin{tabular}{|c|c|c|c|c|}
\hline Species & Family & HTWAGM & HBPMS & HBGMS \\
\hline Aglaia odorata Lour & Meliaceae & + & + & + \\
\hline Alstonia macrophylla Wall. Ex G. Don & Apocynaceae & + & - & + \\
\hline Alstonia scholaris (L.) R. Br. & Apocynaceae & + & + & - \\
\hline Antiaris toxicaria Lesch & Moraceae & + & + & + \\
\hline Archidendron parviflorum Pulle & Leguminosae & - & - & + \\
\hline Artocarpus altilis (Parkinsn ex F. A. Zorn) Fosberg & Moraceae & - & + & - \\
\hline Barringtonia asiatica (L.) Kurtz. & Lecythidaceae & - & + & - \\
\hline Buchanania arborescens (Blume) Blume & Anacardiaceae & - & + & - \\
\hline Callicarpa sp. & Lamiaceae & - & - & + \\
\hline Calophyllum inophyllum $\mathrm{L}$. & Clusiaceae & + & + & + \\
\hline Cananga odorata (Lam.) Hook.f. \& Thompson & Annonaceae & + & - & + \\
\hline Canarium hirsutum Willd & Burseraceae & + & + & + \\
\hline Caryota rumphiana Mart.s & Arecaceae & + & + & + \\
\hline Celtis philipinensis Blanco & Ulmaceae & + & + & - \\
\hline Disoxylum molissimum subsp. molle (Miq.) Mabb & Meliaceae & + & + & - \\
\hline Disoxylum octandrum (Blanco) Merr. & Meliaceae & - & - & + \\
\hline Dracontomelum dao (Blanco.) Merr. \& Rolfe & Anacardiaceae & - & - & + \\
\hline Dyospyros hebecarpa A. Cunn. Ex Benth & Ebenaceae & + & + & + \\
\hline Endospermum moluccanum (Teijsm. \& Binn.) Kurz & Euphorbiaceae & + & + & - \\
\hline Ficus benjamina L. & Moraceae & + & - & - \\
\hline Ficus septica Burm F. & Moraceae & - & - & + \\
\hline Ficus variegata Blume & Moraceae & + & - & - \\
\hline Flindersia amboinensis Poir & Rutaceae & - & - & + \\
\hline Garcinia pichorhiza Miq & Clusiaceae & + & + & + \\
\hline Gnetum gnemon Linn & Gnetaceae & - & + & - \\
\hline Gonocaryum littorale (Blume) & Cardiopteridaceae & - & + & + \\
\hline Haplolobus celebicus H. J. Lam & Burseraceae & - & + & - \\
\hline Haplolobus lanceolatus H. J. Lam & Burseraceae & + & - & - \\
\hline Harpulia arborea (Blanco) Radlk. & Sapindaceae & + & - & - \\
\hline Harpulia cupainioides Roxb. & Sapindaceae & - & + & + \\
\hline Hibiscus tiliaceus L. & Malvaceae & - & + & - \\
\hline Homalium foetidum Benth & Salicaceae & - & + & + \\
\hline Horsfieldia laevigata Warb & Myristicaceae & + & - & - \\
\hline Inocarpus fagifer (Parkinson) Fosberg & Leguminosae & + & + & - \\
\hline Koordersiodendron pinnatum (Blanco) Merr. & Anacardiaceae & + & - & + \\
\hline Lepinopsis ternatensis Valeton & Apocynaceae & + & - & - \\
\hline Licuala sp.1 & Arecaceae & + & + & + \\
\hline Licuala sp.2 & Arecaceae & - & + & + \\
\hline Litsea timoriana Span & Lauraceae & + & - & - \\
\hline Lunatsia amara Blanco & Rutaceae & + & - & - \\
\hline Macaranga aleuritoides $\mathrm{F}$. Muell. & Euphorbiaceae & + & + & - \\
\hline Macaranga mappa (Lam.) Mull. Arg. & Euphorbiaceae & - & + & - \\
\hline Mallotus philippensis (Lam.) Mull. Arg. & Euphorbiaceae & + & - & - \\
\hline Mallotus rhizinoides (Pers.) Muell. Arg. & Euphorbiaceae & - & + & - \\
\hline Mangivera minor Blume & Anacardiaceae & - & - & + \\
\hline Maniltoa browneoides Harms & Leguminosae & + & - & + \\
\hline Morinda citrifolia $\mathrm{L}$. & Rubiaceae & + & - & - \\
\hline Myristica papuana Scheff. & Myristicaceae & + & - & + \\
\hline Neonauclea sp. & Rubiaceae & - & - & + \\
\hline Octomeles sumatrana Miq. & Octomeliaceae & - & - & + \\
\hline Palaquium amboinense Burck. & Sapotaceae & + & + & + \\
\hline Palaquium lobbianum Burck. & Sapotaceae & - & - & + \\
\hline Pandanus spp. & Pandanaceae & + & + & + \\
\hline Picrasma javanica Blume & Simaroubaceae & + & - & + \\
\hline Pimeliodendron amboinicum Hassk & Euphorbiaceae & + & + & + \\
\hline Piper aduncum L. & Piperaceae & - & + & - \\
\hline Polyalthia glauca (Hassk.) Boerl. & Annonaceae & - & + & - \\
\hline Polyalthia sumatrana (Miq.) Kurz & Annonaceae & - & - & + \\
\hline Pometia coreacea Radlk & Sapindaceae & + & + & + \\
\hline Pometia pinnata J. R. Forst. \& G. Forst. & Sapindaceae & + & + & + \\
\hline Pongamia pinnata (L.) Pierre & Leguminosae & - & + & - \\
\hline Premna corymbosa Rottler. \& Willd. & Lamiaceae & + & + & + \\
\hline Pterygota horsfieldii (R. Br.) Kosterm. & Malvaceae & + & + & + \\
\hline Rhus taitensis Guill. & Anacardiaceae & - & + & - \\
\hline Spathiostemon javensis Blume & Euphorbiaceae & + & - & + \\
\hline Sterculia shillinglawii F. Muell. & Malvaceae & - & + & - \\
\hline Swietenia macrophylla Jack & Meliaceae & + & - & - \\
\hline Syzygium malaccense (L.) Merr. \& L. M. Perry & Myrtaceae & + & + & + \\
\hline Terminalia catappa $\mathrm{L}$ & Combretaceae & - & + & - \\
\hline Terminalia complanata K. Schum. & Combretaceae & + & - & + \\
\hline Tetrameles nudiflora $\mathrm{R}$. Br. & Tetramelaceae & - & - & + \\
\hline Vitex pinnata $\mathrm{L}$ & Lamiaceae & - & - & + \\
\hline Total & & 41 & 40 & 41 \\
\hline
\end{tabular}

Note: (+) presence; (-) absence 
Table 2. The association between merbau and coexisting species at three research locations in Mount Meja Natural Tourism Park and Bembab Forest in West Papua Province, Indonesia.

\begin{tabular}{|c|c|c|c|c|c|c|c|c|}
\hline \multirow{2}{*}{ Species } & \multirow{2}{*}{ Family } & \multicolumn{2}{|c|}{ Chi-square score } & \multirow{2}{*}{ Association type } & \multicolumn{3}{|c|}{ Association index } & \multirow{2}{*}{$\begin{array}{c}\text { Association } \\
\text { category }\end{array}$} \\
\hline & & $\mathrm{X}^{2}$ & Table X & & IO & ID & $\mathbf{I J}$ & \\
\hline \multicolumn{9}{|l|}{ HTWAGM (Mount Meja Natural Tourism Park) } \\
\hline Caryota rumphiana & Arecaceae & 4.09 & 3.84 & Positive & 0.75 & 0.72 & 0.56 & Strong \\
\hline Dyospyros hebecarpa A. Cunn. Ex Benth & Ebenaceae & 6.11 & 3.84 & Positive & 0.83 & 0.81 & 0.69 & Strong \\
\hline Garcinia pichorhiza Miq. & Clusiaceae & 6.11 & 3.84 & Positive & 0.83 & 0.81 & 0.69 & Strong \\
\hline Palaquium amboinense Burck. & Sapotaceae & 14.12 & 3.84 & Positive & 0.97 & 0.97 & 0.94 & Strong \\
\hline Pometia coreacea Radlk. & Sapindaceae & 20.00 & 3.84 & Positive & 1 & 1 & 1 & Strong \\
\hline \multicolumn{9}{|l|}{ HBPMS (Bembab coastal forest) } \\
\hline Canarium hirsutum Wild. & Burseraceae & 4.80 & 3.84 & Negative & 0.24 & 0.19 & 0.11 & Weak \\
\hline Caryota rumphiana & Arecaceae & 7.50 & 3.84 & Positive & 0.87 & 0.86 & 0.75 & Strong \\
\hline Endospermum moluccanum (Teijsm. \& Binn.) Kurz & Euphorbiaceae & 8.24 & 3.84 & Positive & 0.91 & 0.90 & 0.82 & Strong \\
\hline Licuala sp.1 & Arecaceae & 14.12 & 3.84 & Positive & 0.97 & 0.97 & 0.94 & Strong \\
\hline Licuala sp.2 & Arecaceae & 14.12 & 3.84 & Positive & 0.97 & 0.97 & 0.94 & Strong \\
\hline Macaranga aleuritoides F. Muell. & Euphorbiaceae & 10.59 & 3.84 & Positive & 0.94 & 0.94 & 0.88 & Strong \\
\hline Mallotus rhizinoides (Pers.) Muell. Arg. & Euphorbiaceae & 14.12 & 3.84 & Positive & 0.97 & 0.97 & 0.94 & Strong \\
\hline Pimeliodendron amboinicum Hassk & Euphorbiaceae & 6.55 & 3.84 & Positive & 0.87 & 0.87 & 0.76 & Strong \\
\hline Pometia coreacea Radlk. & Sapindaceae & 14.12 & 3.84 & Positive & 0.97 & 0.97 & 0.94 & Strong \\
\hline \multicolumn{9}{|l|}{ HBGMS (Bembab mountain forest) } \\
\hline Canarium hirsutum Willd & Burseraceae & 6.11 & 3.84 & Positive & 0.83 & 0.81 & 0.69 & Strong \\
\hline Caryota rumphiana & Arecaceae & 11.67 & 3.84 & Positive & 0.94 & 0.93 & 0.88 & Strong \\
\hline Koordersiodendron pinnatum (Blanco) Merr. & Anarcardiaceae & 9.45 & 3.84 & Positive & 0.94 & 0.94 & 0.88 & Strong \\
\hline Licuala sp.1 & Arecaceae & 15.00 & 3.84 & Positive & 0.97 & 0.97 & 0.94 & Strong \\
\hline Licuala sp.2 & Arecaceae & 15.00 & 3.84 & Positive & 0.97 & 0.97 & 0.94 & Strong \\
\hline Maniltoa browneoides Harms & Leguminosae & 11.67 & 3.84 & Positive & 0.94 & 0.93 & 0.88 & Strong \\
\hline Pometia coreacea Radlk & Sapindaceae & 11.67 & 3.84 & Positive & 0.94 & 0.93 & 0.88 & Strong \\
\hline Spathiostemon javensis Blume & Euphorbiaceae & 6.67 & 3.84 & Positive & 0.90 & 0.90 & 0.82 & Strong \\
\hline
\end{tabular}

Note: IO: Ochiai Index; ID: Dice Index; IJ: Jaccard Index 


\section{Structure of vegetation community in merbau habitat}

The results of inventory showed that the total individuals found growing in the habitat of merbau at the three locations were highest at the sapling stage with 1148 individuals and lowest at the poles stage with 585 individuals (Table 3). Furthermore, the highest number of species was found at the tree stage with 116 species and the lowest at the seedlings with 49 species.

The low number of individuals at the pole stage is likely due to firewood collection by people living around the forest. Based on these results, amount of vegetation found at the live level of sapling is thought to be due to lack of plant encroachment at that level. The three areas of merbau spread naturally is an area of natural forest that is very accessible to people living around the forest. Generally, raw materials of firewood taken from the forest were woody plants at poles and trees stages. Nonetheless, the high number of species around merbau vegetation at the tree stage, indicates that the research location still maintained the diversity of natural forest. As suggested by Endarwati et al. (2017), relatively good natural forest is indicated by the high diversity at the tree stage and the dominance of woody plant species at the younger stages.

\section{Biodiversity indicators of vegetation community in merbau habitat}

Indicators used to measure the diversity of vegetation community around merbau habitat were Margalef species richness index (R), Sorensen similarity index (S), Shannon-
Wiener diversity index (H'), and Pielou evenness index (E). The results of the analysis are presented in Figure 2.

The Margalef species richness index (R) tends to be high if a community has a large number of species and each species is represented by one or few individuals, while the index will be low if the community has a small number of species and each species has a large number of individuals (Rau et al. 2013; Ismaini et al. 2015). The highest species richness index at the stage of seedling was found in the Bembab mountain forest with a value of 1.67 when compared to the other two locations. Similar result was also found at the sapling stage where Bembab mountain forest had the highest richness index with 2.59. In Bembab mountain, richness index at the pole stage was found with 2.62 had the highest than other two locations. At tree stage, Bembab beach forest had the highest with 3.92 when compared to the other locations, but when viewed in more detail, Mount Meja Natural Tourism Park had 3.44 and Bembab mountain forest had 3.56 of the richness index. Value richness index low if $\mathrm{R}<3.5$, instead high if $\mathrm{R}>3.5$ (Maggurran 1988; Pamoengkas et al. 2018). Thus, at the stages of young and pole, richness of species is relatively low. While at the stage of tree is closely high for HTWAGM $(\mathrm{R}=3.44<3.5)$, high for Bembab coastal forest and Bembab mountain forest. The structure of vegetation at the younger stages is influenced by the competition to gain sunlight, nutrition, and water which is presumed as the limiting factor by some species since they cannot survive below large trees (Murdjoko et al. 2020).

Table 3. Vegetatiton structure of community around merbau habitat at three research sites in Mount Meja Natural Tourism Park and Bembab forest in West Papua Province, Indonesia. HBPMS refers to Bembab coastal forest and HBGMS refers to Bembab mountain forest

\begin{tabular}{lcccccccc}
\hline \multirow{2}{*}{ Habitat } & \multicolumn{3}{c}{ Number of species } & \multicolumn{3}{c}{ Number of individuals } \\
\cline { 2 - 9 } & Seedling & Sapling & Pole & Tree & Seedling & Sapling & Pole & Tree \\
\hline HTWAGM & 19 & 25 & 31 & 38 & 312 & 297 & 138 & 147 \\
HBPMS & 12 & 21 & 34 & 38 & 263 & 451 & 234 & 300 \\
HBGMS & 18 & 32 & 35 & 40 & 341 & 400 & 213 & 381 \\
Total & 49 & 78 & 100 & 116 & 916 & 1148 & 585 & 828 \\
\hline
\end{tabular}

Table 4. The results of soil analysis in merbau habitat at three research sites in Mount Meja Natural Tourism Park and Bembab forest in West Papua Province, Indonesia. HBPMS refers to Bembab coastal forest and HBGMS refers to Bembab mountain forest.

\begin{tabular}{|c|c|c|c|c|c|c|c|}
\hline \multirow{2}{*}{ Variables } & & \multicolumn{2}{|r|}{ HTWAGM } & \multicolumn{2}{|c|}{ HBPMS } & \multicolumn{2}{|c|}{ HBGMS } \\
\hline & & Value & Category & Value & Category & Value & Category \\
\hline \multirow[t]{2}{*}{ Soil chemistry } & $\mathrm{pH}\left(\mathrm{H}_{2} \mathrm{O}\right)$ & 7.4 & Neutral & 6.8 & Neutral & 7.4 & Neutral \\
\hline & $\mathrm{CEC}\left(\mathrm{cmol}(+) \mathrm{kg}^{-1}\right.$ & 24.49 & Medium & 18.85 & Medium & 22.52 & Medium \\
\hline \multirow[t]{6}{*}{ Macronutrients } & C-Organic (\%) & 7.1 & Very high & 2.6 & Medium & 2.3 & Medium \\
\hline & $\mathrm{N}-\mathrm{NH}_{4}(\%)$ & 0.53 & High & 0.25 & Medium & 0.18 & Low \\
\hline & $\mathrm{P}_{2} \mathrm{O}_{5}(\mathrm{ppm})$ & 34 & Very high & 12 & Medium & 25 & Very high \\
\hline & $\mathrm{K}(\mathrm{ppm})$ & 113.60 & Very high & 153.60 & Very high & 159.40 & Very high \\
\hline & $\mathrm{Ca}\left(\operatorname{cmol}(+) \mathrm{kg}^{-1}\right.$ & 25.66 & Very high & 18.80 & High & 27.35 & Very high \\
\hline & $\operatorname{Mg}\left(\operatorname{cmol}(+) \mathrm{kg}^{-1}\right.$ & 1.18 & Medium & 4.59 & High & 5.49 & High \\
\hline \multirow[t]{3}{*}{ Micronutrients } & $\mathrm{Fe}(\mathrm{ppm})$ & 6.80 & High & 3.80 & Medium & 4.13 & Medium \\
\hline & $\mathrm{Mn}(\mathrm{ppm})$ & 185.40 & Very high & 9.53 & High & 112.60 & Very high \\
\hline & $\mathrm{Zn}(\mathrm{ppm})$ & 0.95 & Medium & 0.99 & High & 0.94 & Medium \\
\hline \multirow[t]{3}{*}{ Texture } & Sand $(\%)$ & 70.33 & Sandy Loam/SL & 47.13 & Loam/Lay & 21.93 & Clay/L \\
\hline & Silt $(\%)$ & 21.4 & & 36.73 & & 34.47 & \\
\hline & Clay $(\%)$ & 8.2 & & 16.27 & & 43.46 & \\
\hline
\end{tabular}




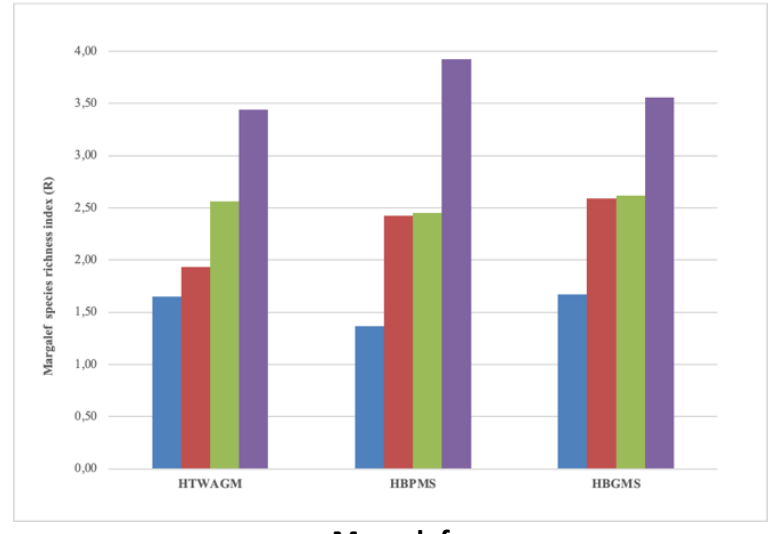

Margalef

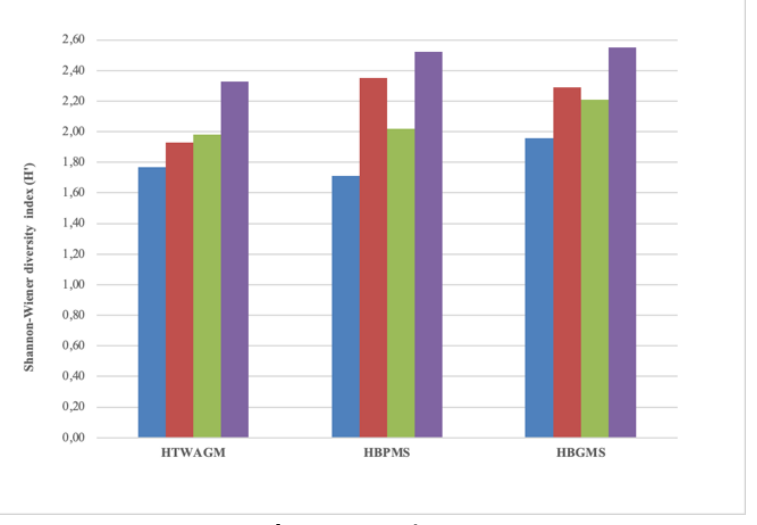

Shannon-Wiener
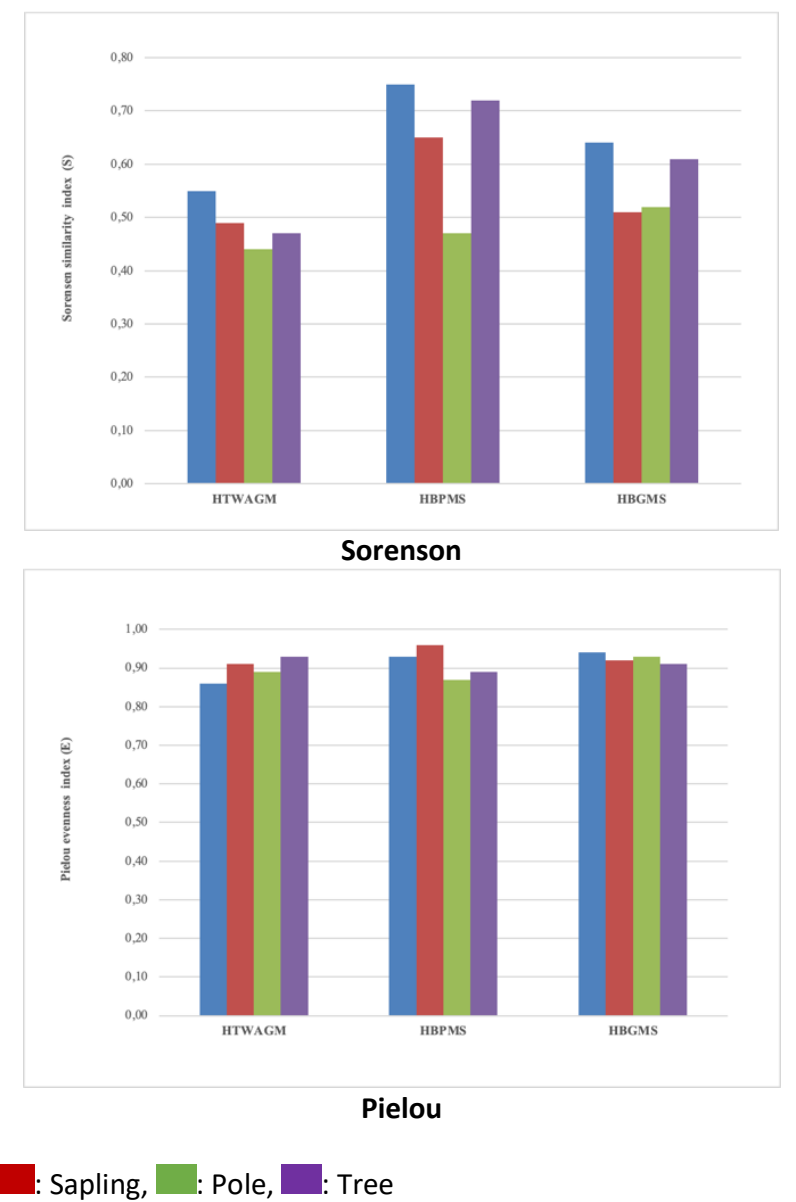

Figure 2. Biodiversity indicators of vegetation community in merbau habitat at three research sites in Mount Meja Natural Tourism Park and Bembab forest in West Papua Province, Indonesia. HBPMS refers to Bembab coastal forest and HBGMS refers to Bembab mountain forest.

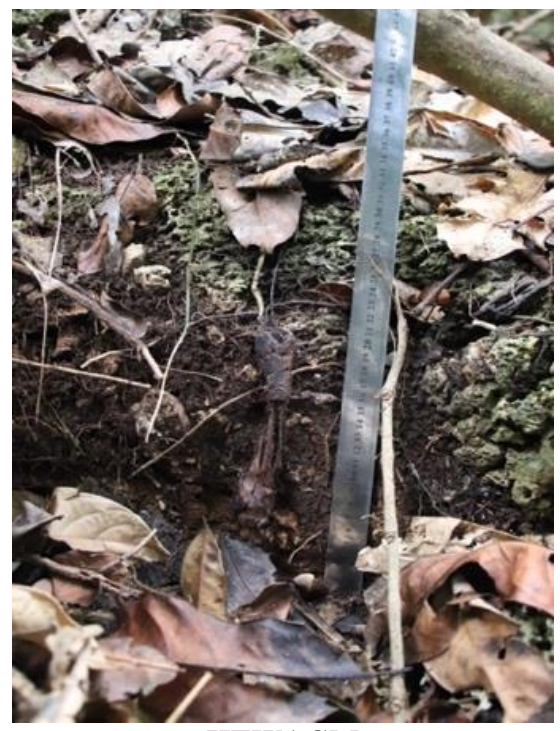

HTWAGM

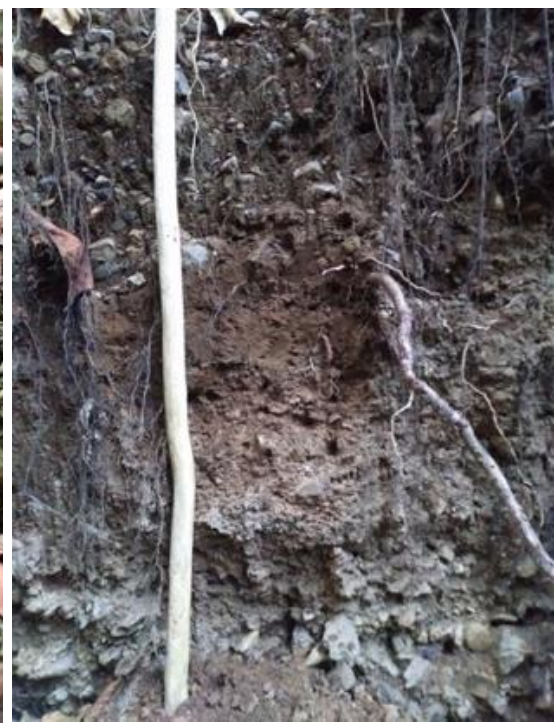

HBPMS

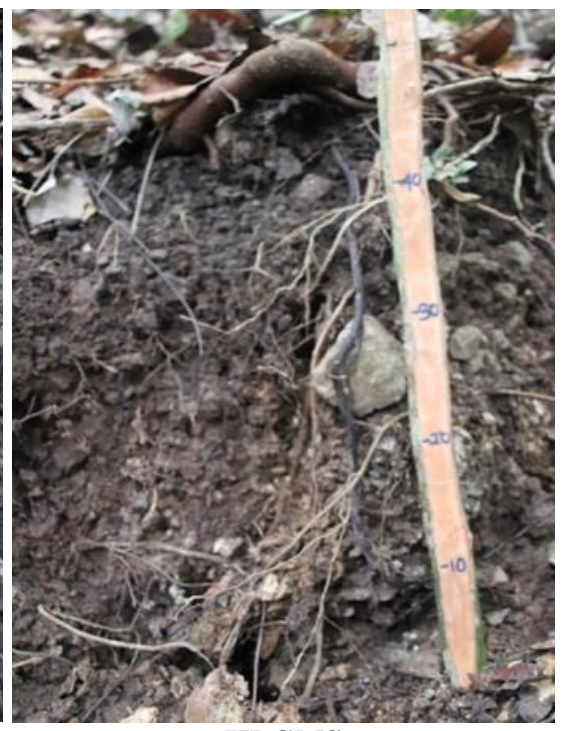

HBGMS

Figure 3. Physical appearance of the soil in merbau habitat at three research sites in Mount Meja Natural Park and Bembab forests in West Papua Province, Indonesia. HBPMS refers to Bembab coastal forest and HBGMS refers to mountain forest

The Sorensen similarity index $(\mathrm{S})$, illustrates the similarity in structure and composition of species between vegetation communities. The higher value of the index indicates the higher similarity of species between two 
communities compared (Odum 1996). Based on the results shown in Figure 2, the vegetation communities in three locations at the seedling and sapling stages are different, but tend to show an average value of similarity index close to and above $0.5(50 \%)$. At the pole stage, the value of $\mathrm{S}$ is close to 0.5 (50\%), except in HTWAGM which is 0.44 (44 $\%)$. While at the tree stage, the $\mathrm{S}$ value indicated tends to be close to and above $0.5(50 \%)$. These results suggest that the vegetation communities in merbau habitat tend to be the same as Mawazin and Subiakto (2013) that if the value of $\mathrm{S}>50 \%$ then the species similarity is high.

The Shannon-Wiener diversity index ( $\left.\mathrm{H}^{\prime}\right)$ indicates the stability of vegetation community in terms of species diversity (Odum 1996; Mawazin and Subiakto 2013). Based on the results presented in Figure 2, the ShanonWiener diversity Index value $\left(\mathrm{H}^{\prime}\right)$, in the three different sites from 1.71-1.96 for seedling stage, 1.93-2.35 for sapling stage, 1.98-2.02 for pole stage and 2.33-2.55 for tree stage. These values suggest that vegetation communities in all three research sites were at stable state since the value of $\mathrm{H}^{\prime}$ is between 1 and 2 (Kent and Paddy 1992).

Similarly, Pielou evenness index (E) had similar pattern with the Shannon-Wiener diversity index value. The evenness index on the three sites ranged from 0.86-0.94 for seedling stage, 0.91-0.96 for sapling stage, 0.87-0.93 for pole stage, and 0.89-0.93 for trees. This indicates that the vegetation diversity in all three locations was evenly distributed since the E value > 0.6 (Maggurran 1988; Brower et al. 1998; Maulana et al. 2019; Fitri et al. 2020).

\section{Soil variables in merbau habitat}

The optimal growth of a vegetation community is very closely related the soil condition. Although all three sites are natural forests, they had different soil properties in terms of physical and chemical attributes as presented in Figure 2 and Table 4.

Mount Meja Natural Tourism Park is a forest area. The soil is dominated by mixed soil and coral reefs. On the other hand, Bembab coastal forest (HBPMS) is dominated by a mixed soil, sand and rocks and Bembab mountain forest (HBGMS) is dominated by a mixture of black soil. While the HBPMS and HBGMS areas are located in one area, but physically the condition of the site is also different. However, the colors in the various horizons were greatly influenced either by organic matter accumulation or mottling (Kome et al. 2021).

The result of analysis showed that the $\mathrm{pH}$ value tended to be same which is categorized as neutral for all research locations with a value range of 6.8-7.4. Cation Exchange Capacity (CEC) was also same for all three locations, with medium category. C-Organic was very high in TWAGM and medium HBPMS HBGMS. C-organic is the main source of food for microorganisms so the greater the value of C-organic is the higher to the number of microorganisms (Yulipriyanto 2010). C-organic soils can also reflect the amount of organic materials such as decomposed leaves (Von Lützow et al. 2008; Paul 2014). Availability of micro-organisms and high decomposition of organic materials, strongly supports the optimal quality of the place to grew (Grigulis et al. 2013; Biau et al. 2013)

The values of macronutrient show that in general the three locations had comparable macronutrients with moderate to very high category, except for nitrogen which was low in HBGMS (Bembab mountain forest) with 0.18 . There is unknown cause of the low nitrogen content in Bembab mountain, but some researchers mentioned that the nitrogen content will be comparable to content of Corganic (Kidanemariam et al. 2013; Purwanto et al. 2014;). In addition, the amount of micronutrients at all three research locations was relatively similar within all moderate to very high categories.

Sutedjo (2002) and Widyantari et al. (2015) suggest that the fertile soil is a soil that has a deep profile (exceeding $150 \mathrm{~cm}$ ); the structure is loose; $\mathrm{pH} 6.0$ - 6.5; nutrient contents available for plants is sufficient and there is no disturbance in the soil for plant to grow. Based on the soil analysis in Table 4, it can be said the soil conditions in all three research locations are optimal for vegetation to grow including merbau.

The composition of the soil texture (Figure 3, Table 4), shows that TWAGM and HBPMS had similarities in percent of the higher sand composition compared with HBGMS. On the contrary, the percentage of clay composition is higher in HBGMS compared with TWAGM and HBPMS. Although there were differences in the percentage of soil texture components in the three locations that were also physically different, merbau and vegetation that grew alongside them were also found in all three locations (Table 1). According to Table 4, there is varies in soil texture percentage (Khalil et al. 2015; Kome et al. 2021). Sandy loam for TWAGM, loam for HBPMS, and clay for HBGMS.

In conclusion, total of 72 species was found coexisting with merbau across at three research sites. There were species that were always found in the three research locations from family Arecaceae namely Caryota rumphiana and Licuala sp 1., Clusiaceae namely Calophyllum inophyllum and Garcinia pichoriza, and Sapindaceae namely Pometia coreacea and Pometia pinnata. The presence of these species indicates positive associations with merbau with strong relationships. In addition Pometia coreacea had the highest Chi-square value $\left(\mathrm{X}^{2}=20.00\right)$ with the value of three association indexes reached maximum value (i.e., IO ranged $=0.94$ 1.00 ; ID ranged $=0.93-1.00$; and IJ ranged $=0.88-1.00$ ). Based on the results of vegetation analysis the vegetation communities in the habitat of merbau had varying vegetation structures and composition as well as biodiversity indicators. Nonetheless, the vegetation communities in all three research locations had very stable conditions. The result of vegetation condition was confirmed with soil analyses in which the physical and chemical properties in term of macro and micronutrients were within the range of optimal conditions for vegetation to grow, including for merbau. 


\section{ACKNOWLEDGEMENTS}

We thank those who have contributed to this research. Specifically, we thank Indonesia Endowment Fund for Education (LPDP) for supporting the author in the implementation of research through research grand provided.

\section{REFERENCES}

Arsyad M. 2017. The association of the palmae family species in the Bajuin Waterfall Area, Tanah Laut Regency. Bioexperiment 3 (1): 39-47. DOI: 10.23917/bioeksperimen.v3i1.3669.

Biau A, Santiveri F, Mijangos I, Lloveras J. 2013. The impact of organic and mineral fertilizers on soil quality parameters and the productivity of irrigated maize crops in semiarid regions. Eur J Soil Biol 53: 5661. DOI: 10.1016/j.ejsobi.2012.08.008

Brower JE, Zar JH, Von Ende CN. 1998. Field and Laboratory Methods for General Ecology.3rd ed. Brown Publisher, USA.

Canastares ED, Vedra SA, Gorospe JG. 2017. Biodiversity and habitat assessment of Mount Malindang, Naawan, Misamis oriental, Philippines. Int Lett Nat Sci 62: 20-27. DOI: 10.18052/www.scipress.com/ILNS.62.20

Endarwati MA, Kurniawan SW, Didik S. 2017. Vegetation biodiversity and ecosystem function: the relationship between density, vegetation diversity and soil filtration in the inceptisols of the Mount Kaw Malang Slopes. Land Land Resour 4 (2): 577-588.

Fitri ZA, Dahalan MP, Ahmad A, Ibrahim TMRT, Latiff A. 2020. Tree community structure and diversity in two forest reserves of Selangor, Peninsular Malaysia. Malay For 83 (1): 84-102.

Greig-Smith P. 1983. Quantitative Plant Ecology. University Press, Iowa.

Grigulis K, Lavorel S, Krainer U, Legay N,Baxendale C, Dumont M, Kastl E, Arnoldi C, Bargett RD, Poly F, Pommier T, Schoter M, Tappeiner U, Bahn M, Clement J-Ch. 2013. Relative contributions of plant traits and soil microbial properties to mountain grassland ecosystem services. Ecology 101 (1): 47-57. DOI: 10.1111/13652745.12014.

Hou D. 1994. Studies in Malesian Caesalpinioidae (Leguminosae). I. The Genera Acrocarpus, Afzelia, Copaifera, and Intsia. Blumea 38 (2): 313-330.

Ismaini L, Lailati M, Rustandi, Sunandar D. 2015. Analysis of the composition and diversity of plants on Dempo Mount, South Sumatra. Proceedings of the National Seminar on the Indonesian Biodiversity Society. Bandung Technology Institute, Jatinangor 13 Juni 2015. [Indonesian]

Kent M, Paddy C. 1992. Vegetation Description and Analysis A Practical Approach. Belhaven Press, London.

Kershaw KA. 1964. Quantitative and Dynamic Plant Ecology. $2^{\text {nd }}$ ed. William Clowes and Sons, London.

Khalil HPSA, Hossain MdS, Rosamah E, Azli NA, Saddon N, Davoudpoura Y, Islam MdN, Dungani R. 2015. The role of soil properties and it's interaction towards quality plant fiber: A review. Renewable Sustai Energi Rev 43: 1006-1015. DOI: 10.1016/j.rser.2014.11.099.

Kidanemariam A, Gebrekidan H, Mamo T, Kibret K. 2012. Impact of altitude and land use type on some physical and chemical properties of acidic soils in Tsegede Highlands, Northern Ethiopia. J Soil Sci 2 (3): 223-233. DOI: 10.4236/ojss.2012.23027.

Kome GK, Enang RK, Yerima BPK. 2021. Soil organic carbon distribution in a humid tropical plain of Cameroon: Interrelationships with soil properties. Appl Environ Soil Sci 2021: 1-18. DOI $10.1155 / 2021 / 6052513$.

Krebs CJ. 1994. Ecology, the Experimental Analysis of Distribution and Abundance. Addison-Wesley Educational Publishers, New York.

Ludwig JA, Reynolds JF. 1988. Statistical Ecology: A Prime on Method and Computing. Wiley and Sons, New York.

Magurran AE. 1988. Ecological Diversity and its Measurement. Chapman and Hall Ltd., London. DOI: 10.1007/978-94-015-7358-0.

Mangold R. 1997. Forest Health Monitoring: Field Methods Guide. USDA Forest Service, USA.

Maulana A, Suyanto P, Widiyatno, Faridah E, Suwignyo B. 2019. The dynamics of succession of vegetation in the post-shifting cultivation area in Central Kalimantan. For Sci J 13 (2019): 181-194. DOI: 10.22146/jik.52433.

Mawazin, Subiakto A. 2013. Natural species diversity and composition of peat swamp forests formerly cut down in Riau. For Rehab 1 (1): 5973

Murdjoko, Agustinus, Jitmau MM, Djitmau DA, Siburian RHS, Ungirwalu A, Wanma AO, Mardiyadi Z, Rumatora A, Mofu WY, Sineri AS, Fatem SM, Worabai D, May NL, Tokede MJ, Warmetan H, Wanggai CB, Wanma JF, Sirami EV, Paembonan JB, Unenor E, Kuswani R, Lekitoo K, Khayati L, Benu NMH. Tambing J, Saragih ASB. 2020. Heterospesific and conspesific associations of trees in lowland tropical forest of New Guinea. Biodiversitas 21 (9): 44054418. DOI: $10.13057 /$ biodiv/d210960

Nugroho JD, Mansur I. 2020. Taxonomy, ecology and silviculture merbau. Regional Research and Development Agency, West Papua Province, Manokwari. [Indonesia]

Odum EP. 1996. Ecological Basics. Gadjah Mada University Press, Yogyakarta. [Indonesian]

Pamoengkas P, Siregar IZ, Dwisutono AN. 2018. Stand structure and species composition of merbau in logged-over forest in Papua, Indonesia. Biodiversitas 19 (1): 163-171. DOI: 10.13057/biodiv/d190123

Paul EA. 2014. Soil Microbiology, Ecology and Biochemistry. Academic Press. DOI: 10.1016/B978-0-12-415955-6.00001-3.

Pratama BA, Laode A, Joeni SR. 2012. Association and characterization of peat swamp forest in Hampagen, Central Kalimantan. J Environ Technol Special Edition of Environmental Day: 69-76. [Indonesian]

Purwanto, Hartati S, Istiqomah S. 2014. The influence of quality and dosage of dead foliage on the potential nitrification of soil and the yield of sweet corn. Soil Sci Agroclima 11 (1): 11-20. DOI: 10.15608/stjssa.v11i1.204

Rau AR, Kusen JD, Paruntu CP. 2013. Mollusk community structure in mangrove vegetation deda kulu, Wori District, North Minahasa Regency. Coast Trop Seas 2 (1): 44-50. DOI: 10.35800/jplt.1.2.2013.2123.

Sadono R, Sirami EV, Marsono D, Murdjoko A, Rachman I. 2014 Structural equation model for population of merbau (Intsia bijuga, Colebr. O. Kuntze) in Gunung Meja natural tourism park of Manokwari in Papua. Adv Envi Biol 8 (17): 1012-1019.

Safe'i R, Wulandari C, Kaskoyo H. 2019. Assessment of forest health in various forest types in Lampung Province. Jurnal Sylva Lestari 7 (1): 95-109. DOI: 10.23960/js11795-109. [Indonesian]

Schulte RPO, Creamer RE, Donellan T, O’Uallachain D. 2014. Fuctional land management: A framework for managing soil-based ecosystem services for sustainable intensification of agriculture. Environ Sci Policy 38: 45-58. DOI: 10.1016/j.envsci.2013.10.002

Sirami EV, Marsono D, Sadono R, Imron MA. 2019. Typology of native species as the shade tree for merbau (Intsia bijuga) plantations in Papua, Indonesia based on ecological species group. Biodiversitas 20 (1): 43-53. DOI: 10.13057/biodiv/d200106.

Solikin. 2015. Composition of plant species in two communities where Stachytarpheta jamaicensis (L) Vahl grows in Gajahrejo Village, Pasuruan Regency and Jeru Village, Malang Regency. Bioexperiment 1 (2): 28-36.

Su SS, Liu JF, He ZS, Hong W, Xu DW. 2015. Ecological species group and interspecific association of dominant tree species in Daiyun mountain national nature reserve. J Mount Sci 12 (3): 637-646. DOI: 10.1007/s11629-013-2935-7

Sutedjo MM. 2002. Fertilizer and How to Fertilize. Rineka Cipta, Jakarta. [Indonesian]

Von Lützow M, Kögel-Knabner L, Ekschmitt K, Matzner E, Guggenberger G, Marschner B, Flessa H. 2006. Stabilization of organic matter in temperate soils: mechanisms and their relevance under different soil conditions - a review. Soil Sci 57 (4): 426-445. DOI: $10.1111 / \mathrm{j} .1365-2389.2006 .00809 . x$.

Widyantari DAG, Dharma KS, Tatiek K. 2015. Evaluasi status kesuburan tanah untuk lahan pertanian di Kecamatan Denpasar Timur. Agroekoteknologi 4 (4): 293-303. [Indonesian]

Windusari Y, Susanto RH, Dahlan Z, Wisno S. 2011. Types association in succession vegetation communities in the double embankment tailings deposition area at PTFI Papua Mining. J Sci - Biota Life Sci 16 (2): 242-251. DOI: $10.24002 /$ biota.v16i2.106.

Yulipriyanto H. 2010. Soil Biology and Its Management Strategies. Graha Ilmu, Yogyakarta. [Indonesian] 